\title{
多スパン山形フレーム構造の三次元折板効果と 遺伝的アルゴリズムを用いた最小重量設計 \\ MINIMUM WEIGHT OPTIMIZATION OF MULTI-SPAN GABLE FRAME STRUCTURES AND THE CUBIC FOLDED PLATE EFFECTS
}

\author{
皆川洋一* \\ Youichi MINAKAWA
}

\begin{abstract}
Multi-span gable frame structures shows significant cubic effects that may reduce the displacements and stress resultants of the frame. The optimal weight may express not only a literal design standard of a structure but also a quantitative evaluation of the cubic effect of the structures. Then, adopting the genetic algorithms to optimize the wcight of the multi-span gable frame structures that have a same plan and height of eaves but have various gable frame pitch and beam pitch, we examine the minimum weight design of the structures and the cubic folded plate effects on the design. It takes much computing time, when the genetic algorithms is applied to the design. In order to reduce the computing time, we adopt equivalent beam theories of the multi-span gable frame structures.
\end{abstract}

keywords : genetic algorithms, optimal weight, multi-span gable frame, folded plate, cubic effect, Gray code 多スパン山形フレーム構造、最小重量設計、遺伝的アルゴリズム、折板効果、三次元効果

1. 序

桁行き方向にいくつかの山形フレームが配置された多スパン山形 フレーム構造は屋根面にブレースが適切に設置されると、この屋根 面が三次元の折板効果を発揮し、各山形フレームの変位や合応力は 平面内において挙動する山形フレームにモデル化された構造体より かなり小さくなることが知られている。鉄骨部材で構成される多ス パン山形フレーム構造は節点数や部材数が多く、立体フレームの解 析法を適用してこの三次元効果を解析するとき、デー夕量や計算量 が多く、労力が多大になる。ここでは、適切に設計されるならば三 次元効果を発揮するものの、節点数や部材数が多い多スパン山形フ レーム構造の最小重量設計問題を扱う。最小重量設計は設計荷重に 対応できる構造体のうち最小の構造体重量となるフレーム形状、山 形フレームのピッチ、部材の配置、断面性能等を定める問題である。 折板効果を示す多スパン山形フレームを対象とするこの問題はふた つの意味を持つと考えられる。ひとつは合理的な設計法としての最 小重量設計の本来の目的である。他方は折板の三次元的な効果を分 量化するひとつの指標を与えることである。多スパン山形フレーム 構造の形状を表すいくつかのパラメータの变化に伴い折板効果が最 小重量設計の解に及はす影響を定量的に評価することを主な目的と して、この問題を検討する。
最適問題の解析方法として、遺伝的アルゴリズムり（GA）を探用 する。この方法は夕フで優れた最適問題の解法として近年広く利用 されてきている2゙。この解法の久点のひとつは、形質の伝達という 制御機構を有するものの試行錯誤の解析の繰り返しであるために、 計算量が膨大となることであろう。

皆川89.99は棟に関する対称変形と逆対称変形する多スパン山形フ レーム構造をそれぞれ剪断変形を考慮に入れたはりにモデル化し、 解析する方法を示した。この方法を適用すると、数百元以上の自由 度を有する多スパン山形フレームを数自由度の系に置換し、設計す るのに十分な精度 (数\%の誤差) で変位や応力を解析することが可 能となる。GAを用いた多スパン山形フレーム構造の最小重量設計問 題にこの解析法を適用して、デー夕量、招よび計算量の削減を図る。 GAの適用に当たって、個体の湟汰の仕方やビット表示を採用する か否かに依存して最適問題解法としての効率に洼違があることが報 告4)されている。ここでは親の選択、および次世代の個体の淘汰に ふたつの方法を採用して、能率を検討する。また、数字をバイナ リーコード (2 進法) 表示すると特定の数字への移行が制限される ことも指摘されている。故に、構造体を表現する数字をビット表現 に置換する方法として、ふたつの方法を採用し、能率の比較を行う。 ひとつは通常利用されている二進法表示（バイナリーコード）であ 
り、他方はCaruana、Schaffer ${ }^{10}$ が提案しているグレイコードである。 このコードを用いて表現されると、連続した数字は 1 ビットの相違 しか存在しないので、ビットコード上で連続した数字へ移行する時 の障害が解消される。

\section{2. 多スパン山形フレーム}

山形フレームが析行き方向と直交して配置され、4箇所の隅角部 に桁行き、梁間の 2 方向に壁体として作用するブレースを有し、㫫 に関して対称な形状を有する多スパン山形フレーム構造を対象とす る。妻壁において屋根は鉛直方向に支持されているものとする。こ の多スパン山形フレーム構造の形状の例をFig.1に示す。材のヤング 率 $E$ 、スパン $L_{y}(=2 a \cos \phi)$ 、桁行き方向長さ $L$ 、軒高 $h_{c}$ 、桁行き方 向の山形フレームのピッチ $s_{x}$ 、およびスパン数 $n_{x}\left(=L / s_{x}\right) 、 一$ 枚の

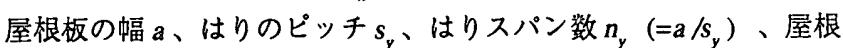
勾配 $\tan \phi$ とする。各山形フレームは析行き方向に垂直に配置され、 壁プレースは 4 カ所の屋根隅角部に配置されるものと仮定する。

\section{2-1＼cjkstart多スパン山形フレーム構造の Timoshenko 梁への置換法}

この多スパン山形フレーム構造の槵に関して対称変形、および逆 対称変形をする三次元構造体はいくつかの仮定（付録A3節に示す） を迸入すると、剪断変形を考慮に入れたはりが弾性床上に設置され たモデルに数学的に置換される。この解析手法8-9)の概要を付録に示 す。結果として、この多スパン山形フレーム構造の㫫に関する対称 変形、および逆対称変形の挙動はそれぞれ次式の汎関数で支配され る。槽造体をこれらふたつの変形に分解したことに対応して、外力 の成分も同様に棈に関する対称成分と逆対称成分に分ける。屋根面 に作用する単位鉛直射影面当りの荷重を対称成分 $q_{s \mathrm{~s}}$ 逆対称成分 $q_{a g}$ 、屋根の法線方向の単位当りの荷重を対称成分 $q_{\mathrm{sn}}$ 、逆対称成分 $q_{n n}$ 、立面に作用する単位当りの荷重を対称成分 $q_{s c}$ 、逆対称成分 $q_{a c}$ 、 および軒に作用する単位長さ当りの水平方向荷重を対称成分 $H_{s}$ 、逆 対称成分 $H_{a}$ と分解して表現する。これら荷重の対称成分、および逆 対称成分を变位成分と共にそれぞれ Fig.2-1、および Fig.2-2に示す。 (1) 横に関する対称变形9)

一枚の屋根板の中央点の桁行き方向に $x$ 軸、平面内の槙に向かう 方向に $y$ 軸、上向き法線方向に $z$ 軸を定めた直交デカルト座標を導 入する。屋根板の $x$ 軸方向の変位 $u_{s}$ 、法線周りの回転 $\theta_{s}$ 、および山 形フレームのはりの $x$ 軸周りの部材角 $R_{s}$ を末知関数とする。 $\Pi_{\mathrm{bD}}^{s}\left(u_{s}, \theta_{s}, R_{s}\right)=2\left[\int_{0}^{L / 2}\left[\frac{1}{2}\left\{(E A)_{n}^{s} u_{s, x}^{2}+(E I)_{n}^{s} \theta_{s, x}^{2}+(G A)_{n}^{s}\left(a R_{s, x} \sin \phi \cos \phi\right.\right.\right.\right.$ $\left.\left.\left.-\theta_{s}\right)^{2}\right\}\right] d x+\sum_{j} s_{x j}\left\{\frac{1}{2} k_{s} R_{s}^{2}-\left(C_{s g}+C_{s n}+C_{s c}+H_{s} a \sin \phi\right) R_{s}\right\}$

$$
\left.+\frac{1}{2} K_{L W}\left(u_{s}+a \theta_{s} / 2\right)^{2^{2}}{ }_{x=L / 2}\right]
$$

where $C_{s g}=-q_{s g} a^{2} \cos ^{2} \phi\left\{2(5+3 \gamma)-\gamma\left(a / h_{c}\right) \sin \phi\right\} /\{4(4+3 \gamma)\}$

$C_{s n}=-q_{s h} g^{2}\left\{2+2(4+3 \gamma) \cos 2 \phi-\gamma\left(a / h_{c}\right) \sin \phi\right\} /\{4(4+3 \gamma)\}$

$C_{s c}=q_{s c} h_{c}^{2}\left\{3+2(5+3 \gamma)\left(a / h_{c}\right) \sin \phi\right\} /\{4(4+3 \gamma)\}$

$k_{s}=12\left(D_{2} / a\right)\left\{1+\gamma\left(3+3\left(a / h_{c}\right) \sin \phi+\left(a / h_{c}\right)^{2} \sin ^{2} \phi\right)\right\} /(4+3 \gamma)$

$K_{L w}=E A_{L w} / s_{x} /\left[\left(1+h_{c}^{2} / s_{x}^{2}\right)^{3 / 2}+2 A_{L w} / A_{y}\left(h_{c} / s_{x}\right)^{3}\right]$

$\gamma=a D_{d}\left(h_{c} D_{2}\right)$

$A L W:$ 析行き方向端部に配置されたブレースの断面積

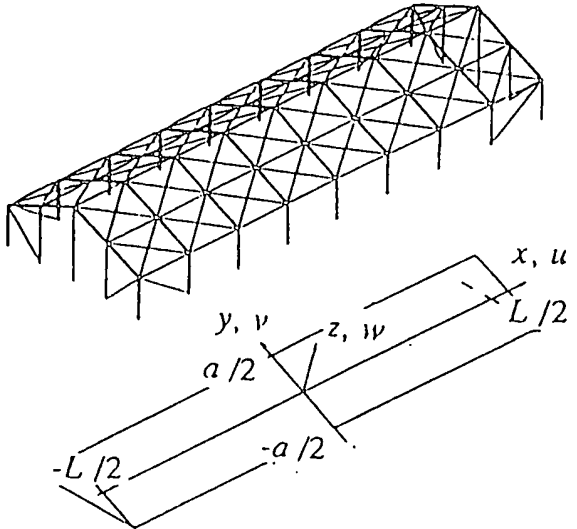

Fig.1 Overall View of Gable Frames

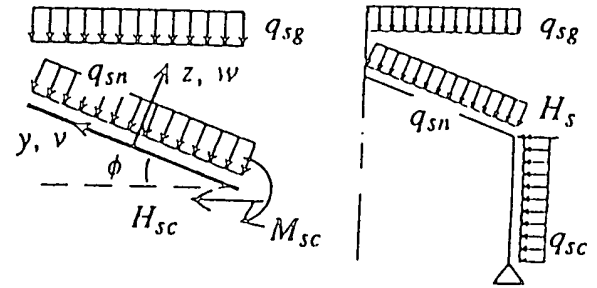

Fig.2-1 Displacement \& Force Components of Symmetric Deformation

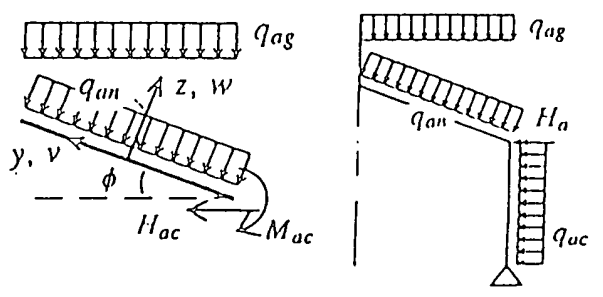

Fig.2-2 Displacement \& Force Components of Anti-Symmetric Deformation

(2) 㫫に関する逆対称変形 8 )

棟における短辺方向の水平变位 $\boldsymbol{d}_{H}$ 棲における鉛直軸周りの屋根 板の回転を $\theta_{z}$ とする。

$\Pi_{\mathrm{bD}}^{a}\left(\theta_{2}, d_{H}\right)=?\left[\int_{0}^{L / 2} \frac{1}{4}\left\{(E I)_{2}^{a} \theta_{2, x}^{2}+(G A)_{i}^{a}\left(d_{H_{x}, x}-\theta_{2}\right)^{2}\right\} d x+\frac{1}{2} K_{e, 1} d_{H}^{2}\right.$ $+\frac{1}{2} K_{L w} \theta_{z}^{2} a^{2} \cos ^{2} \phi+\sum_{j} s_{x j}\left(\frac{1}{4} k_{a c} d_{H^{-}}^{2}\left(C_{a n}+C_{a g}+C_{a c}+H_{a}\right) d_{H}\right)$

where $\left.k_{a c}=6 D_{d} /(1+\gamma) h_{c}^{3}\right\}, C_{a g}=\gamma q_{a g} a^{2} \cos ^{2} \phi /\left\{8 h_{c}(1+\gamma)\right\}$,

$\left.C_{a n}=q_{a n} a\left\{(1+\gamma) \sin \phi+\gamma a /\left(8 h_{c}\right)\right\} /(1+\gamma), C_{a c}=(5+4 \gamma) q_{a c} h_{d} / 8(1+\gamma)\right\}$

$K_{\text {ew }}=E A_{\text {ew }} \cos ^{2} \phi /\left[s_{y}\left(\cos ^{2} \phi+h_{c}^{2} / s_{y}^{2}\right)^{3 / 2}+2 A_{e w} / A_{y}\left\{a+s_{y}\right.\right.$

$\left.\left.+h_{c}\left(h_{c} / s_{y}+\sin \phi\right)\left(3 h_{c} / s_{y}+2 \sin \phi\right)\right\} / 3\right]$

Aew : 妻壁端部に配置されたブレースの断面積

(3) 外力

屋根フレームの単位面積当りの固定荷重（自重、積載荷重） $q_{d}$ 単

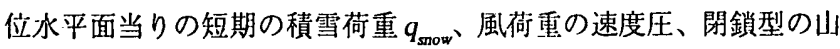
形フレームの風力係数は「建築基準法施行令」の第87条を用いて算 定する。各外力を対称変形、および逆対称変形の成分、および長期 荷重、短期荷重に区別すると、荷重成分は次のように定義される。 1) 対称変形

長期荷重 $q_{s g}=q_{d} / \cos \phi, q_{s n}=0, q_{s c}=0, H_{s}=0$ 短期荷重 $q_{s g}=q_{s n o w}, q_{s n}=(0.65 \sin \phi-0.5) p_{r}, q_{s c}=0.1 p, H_{s}=0.05 p h_{c}$ (3-2) 2) 逆対称変形 
長期荷重 $q_{a g}=0, q_{a n}=0, q_{a c}=0, H_{a}=0$

短期荷重 $q_{a g}=0, q_{a n}=0.65 p_{r} \sin \phi, q_{a c}=0.3 p, H_{a}=0.15 p h_{c}$ ここに、 $\begin{aligned} & p_{r}=60 \sqrt{h \sqrt{ } / 2} / 10^{8} \text { tonf } / \mathrm{cm}^{2} \\ & p=60 \sqrt{h_{c}+a / 2 \tan \phi} / 10^{8} \text { tonf } / \mathrm{cm}^{2}\end{aligned}$

(4) 解析

沉関数 (1) 式、および (2) 式へRitz 法を適用して解析する。対称 変形の3個の未知関数、および逆対称変形の 2 個の未知関数はそれぞ れ3 項（N=3）までの Fourier級数を用いて仮定 ${ }^{8.9}$ したたただし、逆 対称変形の未知関数 $d_{H}$ はこれらの項に定数項も加えた 称変形は未知数 9 個、逆対称変形は未知数 7 個を用いた解析となる。

\section{2-2 解析条件と制約条件}

屋根面は面内の岡性を有しているので、山形フレームの挫屈の影 響を無視する。また、中間部に配置される山形フレームは同一断面 を有し、妻壁を構成する山形フレームは中間部のそれの $1 / 2$ の断面性 能を有すると仮定した。この構造は通常水平力として風荷重の方が 地震荷重よりも大きくなるので、ここでは短期の荷重として、風荷 重のみを考慮する。多スパン山形フレーム構造の渵足すべき応力、お よび変形に関する制約条件を示す。

a. 応力に関する制約条件

1）山形フレームの棟において、引張りおよび圧縮の最大縁応力度が 許容応力度以下である。

2）柱頭において、引張りおよび任縮の最大縁応力度が許容応力度以 下である。

3）はりの引張、および圧縮の最大縁応力度は許容応力度以下である。 4) 各山形フレーム間の剪断力に起因する屋根ブレースの引張応力度 が許容応力度以下である。この応力度は最大 4 筫所で検討される。 5) 妻壁のひとつの隅点に配置されたブレースは軒の高さから上に作 用する風荷重による水平力を負担しても許容応力度以下である。ブ レースは引張、および圧縮両方の応力を伝達できるものと仮定する。 6) 桁行き端部の壁面の一本のブレースは桁行き方向に作用する風荷 重の全荷重の $1 / 4$ を負担しても許容応力度以下である。

\section{b. 変形に関する制約条件}

7）棟の長期、および短期の鉛直方向たわみがスパンのそれぞれ 1/300、および $1 / 120$ 以下である。

8）軒の長期、および短期の変形角（水平変位/軒高）がそれぞれ 1/300、および $1 / 120$ 以下である。

9）屋根に作用する荷重を等分布荷重としたとき、各はりの屋根面の

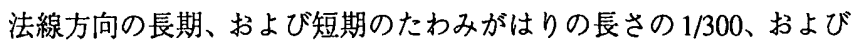
1/120 以下である。

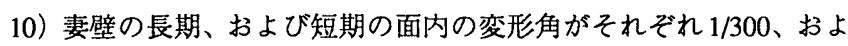
び 1/200 以下である。

「建築基準法施行令」において規定されている変形制限の数値は 地震時の水平力による層間変形角 $1 / 200$ 、または $1 / 120$ のみである。ま た、建築学会の「鋼構造設計規準」の10章に通常の場合にはりの（長 期の）たわみはスパンの 1/300 以下、片持ちはりについては 1/250以 下と記述されている。これらを考虑して、棟やはりの短期のたわみ、 妻壁や軒の長期の変形角を上記のように定めた。 c. 形状に関する制約条件

11）山形フレームのピッチ $s_{x}$ は $200 \mathrm{~cm}$ 以上 $1100 \mathrm{~cm}$ 以下である。

12）はりのピッチ $s_{y}$ は $600 \mathrm{~cm}$ 以下である。

これらは現実性を持たせるために導人された制約である。

項目 4）は屋根板の 4 筒所で検討されるので、制約条件は合計 15 個である。

3. 遺伝的アルゴリズム

3-1 遺伝的アルゴリズムの概要

人口を $N_{\mathrm{pop}}$ と表す。この解析におけるパラメータは13個ある。こ れらのパラメータをビット表現した染色体を用いる。交叉は各パラ メータに対応する染色体に一点交叉を適用する。すなわち、染色体 全体では 13 点交义となる。突然変異は子の染色体の各ビット毎に $p_{m}$ の確率でビットが反転する方式を採用した。これらは後述するすべ てのモデルに共通して適用された。親の選択、淘汰の仕方にふたつ の考え方を導入する。「確率モデル」(Pモデル) と「家族内汻汰モ デル」(Fモデル) と名付ける。

(1) 確率モデル（Pモデル）

a. 適応度のスケーリングとして、評価関数 (4-2に示す) の平均值 を 100 とした偏差值を導入し、これを評洒換算値と表す。この值が 魚となる個体の評価換算値は 0 とする。

b. 世代ギャップ (generation gap) .が 0.5 となるよう評価換算值の小 さい $N_{\text {pof }} / 2$ 假の個体を淘汰する。

c. 世代ギャップが 0.5 となるように、 $N_{\text {poo }} / 4$ 組の親を評価換算值の 值に応じたルーレットルール4)に従って選択する。一組の親は子を 2 個体つくる。

d. 新しく生まれた $N_{\text {pop }} / 2$ の各々にこの代代で淘汰される各個体の 染色体を1及の確率で伝達する。淘汰される個体を含め、親は 3 個体 と考えることも可能。

このPモデルは淘汰や親になる確率等がスケーリングされた現在 の適応度（評価換算値）に依存して定められる。

(2) 家族内淘汰モデル（Fモデル）

a. 適応度のランクに従って上位から 2 個体づつの親を選び、合計 $N_{\text {poop }} / 2$ 組の組み合わせ（全個体が親になる）をつくる。

b. 各ペアの親から 2 個体の子をつくる。

c. 親と子、合わせて 4 個体の適応度を判定し、このなかで大きな適 応度を有する2個体を次世代とする。

このFモデルでは評価値に関係なくどの個体も親になり、親と子 の中で適応度が大きな2個体が次世代として、生存することになる。

\section{3-2 ビットコード}

染色体として二進法表示されたコードを利用する。このコードと 对応する数字の対応にふたつの方法、...進法コード（Binary Code） とグレイコード 10.1)（Gray Code）を適用する。十進法の0から 8 まで の数字とこれらのコードの対応を Table1 に示す。

Table1 Code Expressions of Numbers

\begin{tabular}{|l|ccccccccc|}
\hline integer & 0 & 1 & 2 & 3 & 4 & 5 & 6 & 7 & 8 \\
\hline Binary Code & 0000 & 0001 & 0010 & 0011 & 0100 & 0101 & 0110 & 0111 & 1000 \\
Gray Code & 0000 & 0001 & 0011 & 0010 & 0110 & 0111 & 0101 & 0100 & 1100 \\
\hline
\end{tabular}


十進法の 1 と 2 は徸り合う数字であるが、二進法コードにおいて それぞれ 01 および 10 と表され、ふたつのビットが共に変化しなけ れば表現できない大きな陽たりのあるコードである。しかしながら、 グレイコードではそれぞれ01、および11となり1ビットが変化すれ ば相互に移行できる隆接したコードとなる。

\section{4. 最小重量設計モデルとその解析}

4-1 多スパン山形フレームの最小重量設計のパラメータ

多スパン山形フレームの形状 $L_{y} 、 L 、$ 及び $h_{c}$ を与元、13 個のパラ メータとその変化の箸囲をTable 2に示す。表中のパラメータの定義 域に用いられた大カッコ [] は Gaussの記号である。これらのパラ メータについて説明する。屋根の勾配は８種類、山形フレームピッ チ、および屋根板に設置される梁間の豃を与える $n_{x}$ および $n_{y}$ はそ れぞれ16種額に変化する。山形フレーム、およびはりとして利用し た合計 20 種類のH型鋼の規格、名称、断面積、強軸方向の断面係数、 強軸、及び弱軸方向の断面二次半径を Table 3 に示す。鋼材は SS 400 (ヤング率 $\mathbb{E}=2100 \mathrm{t} / \mathrm{cm}^{2}, F=2.4 \mathrm{t} / \mathrm{cm}^{2}$ ) とした。山形フレームを構成す る H 型銅はTable 3 の No.5から No.20までの 16 種類、はりを禈成す るH型鎡はTable 3 のNo.1からNo.16までの16種類から選択される。 Aew、ALw はそれぞれ妻壁、および析行き方向のブレース壁として 屋根の隅点に設置されるブレースの断面積を表し、それぞれ8種類 の変化がある。 $x 1 /$ 、および $x 2 / L$ は屋根板に配置されるプレースの 致が変化する位置を与える。結果的に、一故の屋根板の桁行き方向 の二等分線の一方にある $n x / 2$ 個の山形フレーム間を最大 4 分割し、 中央から端部に向かってそれぞれ断面積 Abr1、Abr2、Abr3、および $A b r 4$ のプレースを配置する。系の変化の場合の数は $2^{43}$ 通りとなる。

ここで铪討する構造体の重量は山形フレーム、はり、屋根ブレー ス、壁プレースの重量の総計であり、重量を平面の面積を用いて除 した量を単位面積当りの構造体の重量（単位: $\mathrm{kgf} / \mathrm{m}^{2}$ ) と表現する。 間柱、もや、胴差等の重量は構造体の重量に含まれていない。

Table2 Variation Range of Parameters

\begin{tabular}{|c|c|}
\hline & variation range \\
\hline $\tan \phi$ & $0.05,0.1,0.15,0.2,0.25,0.3,0.4,0.5$ \\
\hline$n_{x}$ & $n_{x}=2 i(i=1, \ldots, 16)$ \\
\hline$n_{y}$ & $n_{y}=i(i=1, \ldots, 16)$ \\
\hline Gable & from No.5 to No.20 in Table3 (H-shaped Steel) \\
\hline Beam & from No.1 through No.16 in Table 3 (H-shaped Steel) \\
\hline$A_{\text {ov }}$ & $A_{e W}=8.727 \times i \quad(i=1, \ldots, 8)$ \\
\hline$A_{\text {L" }}$ & $A_{L W}=8.727 \times i \quad(i=1, \ldots, 8)$ \\
\hline$x_{1} / L$ & $x_{1} / L=i / 36(i=1, \ldots, 8)$ \\
\hline$x_{2} / L$ & $x_{2} / L=(i+9) / 36(i=1, \ldots, 8)$ \\
\hline$A_{t r 1}$ & $A_{b r 1}=7.527 \times i(i=1, \ldots, 8)\left(0 \leq x n_{x} / L / 2 \leq\left[x_{1} n_{x} / L / 2\right]\right)$ \\
\hline$A_{t \rightarrow 2}$ & $A_{b r 2}=7.527 \times i \quad(i=1, \ldots, 8) \quad\left(\left[x_{1} n_{d} / L / 2\right] \leq x / L \leq\left[x_{2} n_{x} / L / 2\right]\right)$ \\
\hline$A_{0 \times 3}$ & $A_{b r 3}=7.527 \times i \quad(i=1, \ldots, 8) \quad\left(\left[x_{2} n_{d} / L / 2\right] \leq x / L \leq\left(1-2 / n_{x}\right) / 2\right)$ \\
\hline$A_{b \rightarrow 4}$ & $A_{b r 4}=7.527 \times i \quad(i=1, \ldots, 8)\left(\left(1-2 / n_{x}\right) / 2 \leq x / L \leq 1 / 2\right.$ \\
\hline
\end{tabular}

Table 3 H-Shaped Steel \& Properties

\begin{tabular}{|c|llcll|}
\hline No. & H-shaped Steel & $\begin{array}{l}A \\
\mathrm{~cm}^{2}\end{array}$ & $\begin{array}{l}Z_{x} \\
\mathrm{~cm}^{3}\end{array}$ & $\begin{array}{l}i_{x} \\
\mathrm{~cm}\end{array}$ & $\begin{array}{c}i_{y} \\
\mathrm{~cm}\end{array}$ \\
\hline 1 & $\mathrm{H}-150 \times 75 \times 5 \times 7$ & 17.85 & 88.8 & 6.11 & 1.66 \\
2 & $\mathrm{H}-175 \times 90 \times 5 \times 8$ & 23.04 & 139 & 7.26 & 2.06 \\
3 & $\mathrm{H}-198 \times 99 \times 4.5 \times 7$ & 23.18 & 160 & 8.24 & 2.21 \\
4 & $\mathrm{H}-200 \times 100 \times 5.5 \times 8$ & 27.16 & 184 & 8.24 & 2.22 \\
5 & $\mathrm{H}-248 \times 124 \times 5 \times 8$ & 32.68 & 285 & 10.4 & 2.79 \\
6 & $\mathrm{H}-250 \times 125 \times 6 \times 9$ & 37.66 & 324 & 10.4 & 2.79 \\
7 & $\mathrm{H}-298 \times 149 \times 5.5 \times 8$ & 40.80 & 424 & 12.4 & 3.29 \\
8 & $\mathrm{H}-300 \times 150 \times 6.5 \times 9$ & 46.78 & 481 & 12.4 & 3.29 \\
9 & $\mathrm{H}-346 \times 174 \times 6 \times 9$ & 52.68 & 641 & 14.5 & 3.88 \\
10 & $\mathrm{H}-350 \times 175 \times 7 \times 11$ & 63.14 & 775 & 14.7 & 3.95 \\
11 & $\mathrm{H}-396 \times 199 \times 7 \times 11$ & 72.16 & 1010 & 16.7 & 4.48 \\
12 & $\mathrm{H}-400 \times 200 \times 8 \times 13$ & 84.12 & 1190 & 16.8 & 4.54 \\
13 & $\mathrm{H}-446 \times 199 \times 8 \times 12$ & 84.30 & 1290 & 18.5 & 4.33 \\
14 & $\mathrm{H}-450 \times 200 \times 9 \times 14$ & 96.76 & 1490 & 18.6 & 4.40 \\
15 & $\mathrm{H}-496 \times 199 \times 9 \times 14$ & 101.3 & 1690 & 20.3 & 4.27 \\
16 & $\mathrm{H}-500 \times 200 \times 10 \times 16$ & 114.2 & 1910 & 20.5 & 4.33 \\
17 & $\mathrm{H}-506 \times 201 \times 11 \times 19$ & 131.3 & 2230 & 20.7 & 4.43 \\
18 & $\mathrm{H}-596 \times 199 \times 10 \times 15$ & 120.5 & 2310 & 23.9 & 4.05 \\
19 & $\mathrm{H}-600 \times 200 \times 11 \times 17$ & 134.4 & 2590 & 24.0 & 4.12 \\
20 & $\mathrm{H}-606 \times 201 \times 12 \times 20$ & 152.5 & 2980 & 24.3 & 4.22 \\
\hline
\end{tabular}

\section{4-2 最小重量設計の評価関数}

最小重量設計を行う上で記述を避けられない問題のひとつは評価 関数であろう。制約条件を満足する解のなかから重量が小さいもの に高い評価を与えれば良いのであるから一見簡単に見えるものの、 注意しなければ成らない事項がある。

制約条件を満足しない解にはペナルティを与えて処理するのが通 例である。最適解すなわち最小重量解はどのひとつの部材の断面性 能を小さくしても制約炛件を満足しなくなる。制約条件を満足しな い解のペナルティを過度に大きくすると、重量よりも制約条件を満 足することの方が高く評価されることになる。この結果、最小重量 への収束の速度が遅くなる。一方、ペナルティを小さくすると制約 条件を満足することが軽く判定され、相対的に重量の小さな解が高 く評価され、制約条件を满足する本来の最適解に取束しなくなる。

各個体 $j$ の評価関数 $f_{j}$ を定める。評価関数は制約条件をす心゙て満 足するとき重量の逆数を表し、2-2に示した 15 個の制約条件のうち の $V_{p j}$ 個を渵足しないとき $V_{p j}$ 值に関して指数関数的に評価値が小さ くなる次式を用いる。

$$
f_{j}=\exp \left(c_{p} \times V_{p j}\right) / W_{j}
$$

ここに、定数 $c_{p}=-0.43 、 W_{j}$ は個体の構造体の重量である。

$$
W_{j}=w_{s}\left\{n_{x} \times\left(2 h_{c}+L_{y} / \cos \phi\right) A_{y}+2\left(n_{y}+1\right) L A_{x}+4 A_{e w} \sqrt{h_{c}^{2}+s_{y}^{2} \cos ^{2} \phi}\right.
$$

$$
\left.+4 A_{L w} \sqrt{h_{c}^{2}+s_{x}^{2}}+A_{b r F} \sqrt{s_{x}^{2}+s_{y}^{2}}\right\}
$$

where $A_{b r F}=2\left\{A_{b r 1}\left[n_{y} / 2 x_{1} / L\right]+A_{b r 2}\left(\left[n_{y} / 2 x_{2} / L\right]-\left[n_{y} / 2 x_{1} / L\right]\right)\right.$

$$
\left.\left.+A_{b r 3}\left(n_{y} / 2-1-n_{y} / 2 x_{1} / L\right]\right)+A_{b r 4}\right\}
$$

ここに、, $w_{s}=7.86 \times 10^{-6}$ tonf $/ \mathrm{cm}^{3}$ : 鋼材の単位体積当りの重量、大 カッコ []はGauss の記号。W の第 1 項は山形フレーム、第 2 項は はり、第3項は妻壁ブレース、第4項は桁行き万向の壁のブレース、 第 5 項は屋根ブレースの重量を表す。定数 $c_{p}$ は試行錯誤を行って定 めた。上記の值を用いたとき、制約条件を満足しない解が評価值の 最上位を占める場合は出現しなかった。 


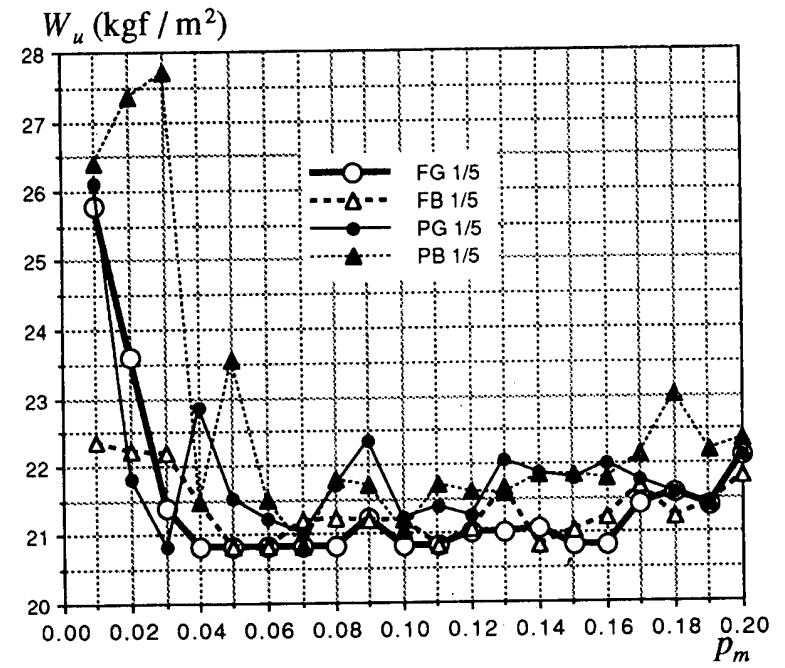

Fig.3 The Best $W_{u}$ vs $p_{m}$ Curves out of 5 Trials $\left(q_{d}=80 \mathrm{kgf} / \mathrm{m}^{2}\right)$

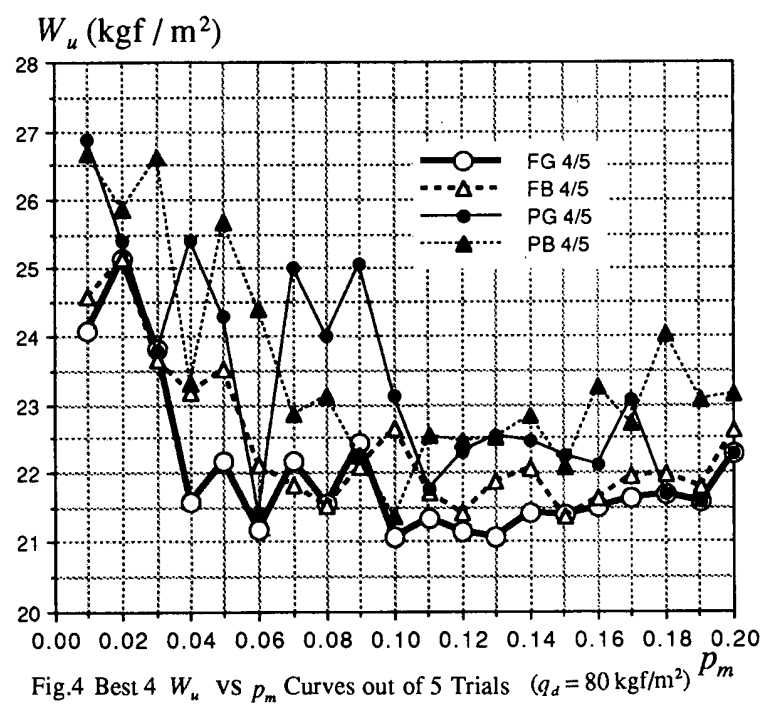

4-3 4つの解析手法の特性と突然変異の影響

スパン $L_{y}=2400 \mathrm{~cm}$ 、桁行き方向長さ $L=4800 \mathrm{~cm}$ 、軒高 $h_{c}=600 \mathrm{~cm}$ 、 屋根面積当りの固定荷重を $80 \mathrm{kgf} / \mathrm{m}^{2}$ 、短期の積雪荷重を水平射影面当 り $60 \mathrm{kgf} / \mathrm{m}^{2}$ とする。

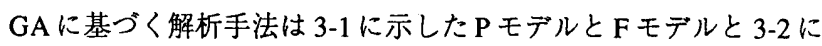
示した二進法コード（B）とグレイコード（G）の組み合わせた 4 つ の解法を用いる。これらは PB、PG、FB、FG と表現される。先頭の 文字がPモデル、あるいはFモデルを、末尾の文字が二進法コード、 あるいはグレイコードを探用することを表す。子の染色体の各ビッ 卜を反転する突然変異の確率 $p_{m}$ と表す。この確率と最良解の関係を 検討する。本論文のすべての解析において、人口を $N_{p o p}=16$ とする。 突然変異の確率 $p_{m}$ を 0.01 から 0.20 まで 0.01 の増分で変化させて、上 記の4つの解法を用いて各確率に対応する最適化問題を5回づつ解析 し(各試行は 1200 世代まで実行)、得られた最小重量（5回の試行の 中での最良解）と突然変異の確率 $p_{m}$ との関倸を Fig.3に示す。図中の

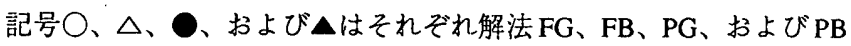
に対応する。5回の試行の最良解のうち、最も大きな重量を与えた解 を除いた 4 回の最小重量の平均値（最良解のベスト 4 の平均值）を Fig.4に示す。図中の記号は Fig.3 と同一である。

これらのデータから次のような結論を得ることができる。

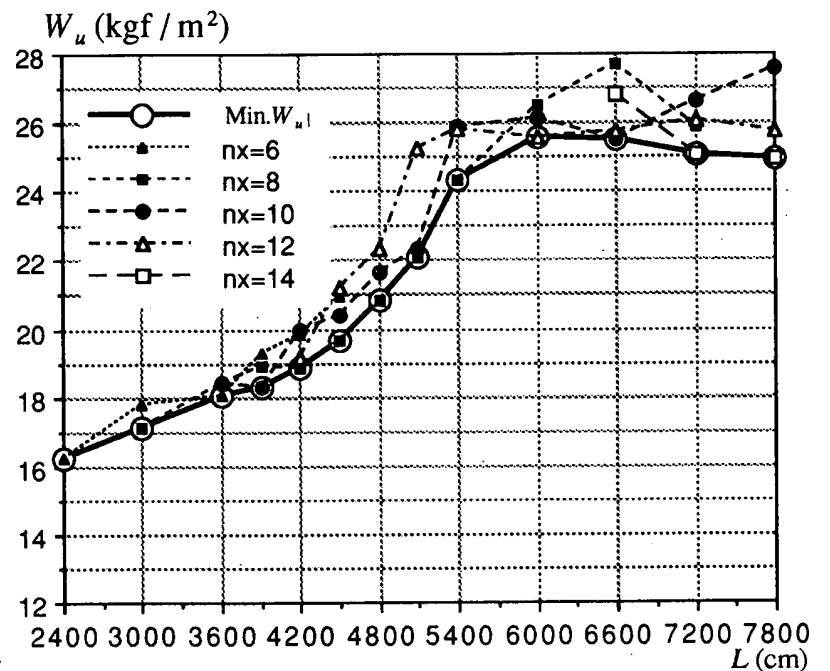

Fig.5 Min. $W_{u}$ vs Length $L$ Curves for Each $n_{x}\left(q_{d}=80 \mathrm{kgf} / \mathrm{m}^{2}\right)$

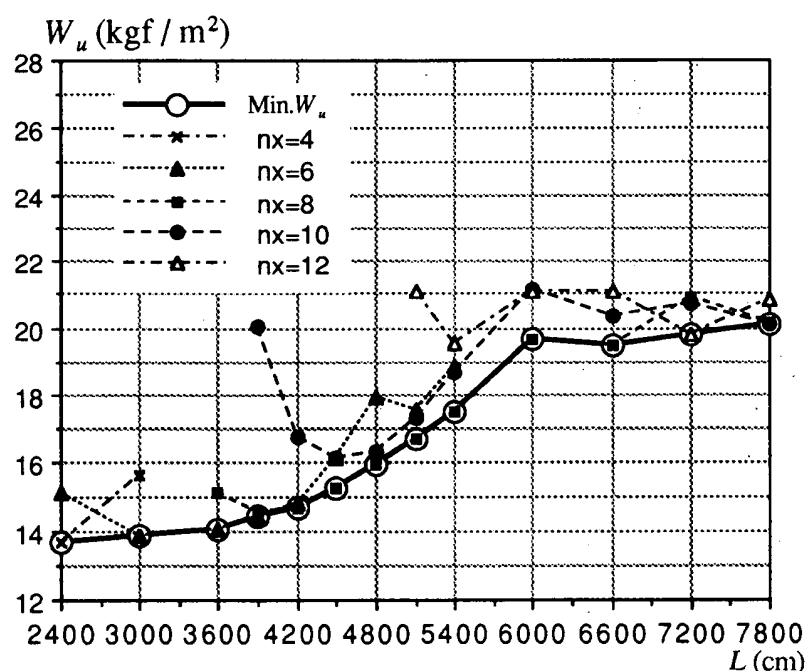

Fig. 6 Min. $W_{u}$ vs Length $L$ Curves for Each $n_{x}\left(q_{d}=50 \mathrm{kgf} / \mathrm{m}^{2}\right)$

1. FG (O印) とPG (O印)、あるいはFB ( $\triangle$ 印) とPB (ム印)を

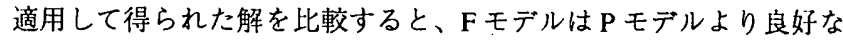
最良解を与え、良好な解を与える確率 $p_{m}$ も広い。

2. Fモデルと組み合わせたときグレイコードの方が突然変異の確率 の広い領域において二進法コードより良好な解を与える。FBモデル

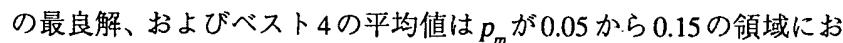
いてFGモデルのそれらよりそれぞれ $1.0 \%$ 、および $2.6 \%$ 大きな平均 值となる。Pモデルは能率が極端に悪くなる突然変異の確率を有す

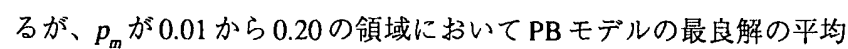
值は PG モデルより $3.5 \%$ 大きな值となる。

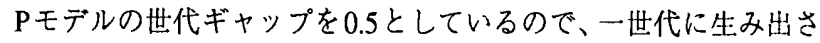
れ、淘汰の対象とされる個体数はFモデルの1/2であり、計算量も䄪 1/2である。故に、上記1.の知見を同一の計算量のもとで、再検討す

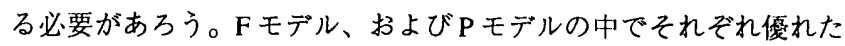
性能を示したFGモデル、およびPGモデルのふたつの解法を採用し、 両者の性能が十分発揮できると判断される突然変異の確率 $p_{m}$ が 0.06 から 0.12 の領域において確率の增分を 0.01 として検討する。

FGモデルは世代数 1200 まで計算したデー夕、PGモデルは世代数 2400 まで解析したものを利用して、5回の北行を実行して得られた

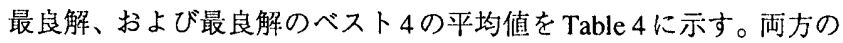


最小重量の値とも FG モデルの方が良好な解を与えている。

Table 4 Best Solutions out of 5 Trials (unit : $\mathrm{kgf} / \mathrm{m}^{2}$ )

\begin{tabular}{|c|cc|cc|}
\hline \multirow{2}{*}{ pm } & \multicolumn{2}{|c|}{$\begin{array}{c}\text { The Best Solution } \\
\text { out of Five Trials }\end{array}$} & \multicolumn{2}{c|}{$\begin{array}{c}\text { Mean Value of Best Four } \\
\text { Solutions out of Five Trials }\end{array}$} \\
\cline { 2 - 5 } & FG-Model & PG-Model & FG-Model & PG-Model \\
\hline 0.06 & 20.836 & 20.836 & 21.170 & 21.104 \\
0.07 & 20.836 & 20.836 & 22.148 & 24.907 \\
0.08 & 20.836 & 21.379 & 21.549 & 22.796 \\
0.09 & 21.219 & 22.334 & 22.432 & 24.377 \\
0.10 & 20.836 & 20.836 & 21.055 & 22.852 \\
0.11 & 20.836 & 21.208 & 21.335 & 21.488 \\
0.12 & 21.017 & 21.198 & 21.143 & 21.985 \\
\hline mean & 20.917 & 21.232 & 21.547 & 22.787 \\
\hline
\end{tabular}

故に、同一計算量の下で比較しても、FG モデルの方がPG モデル より性能が飠いと判断できる。また、最良解における差違よりも、5 回のうちのベスト4の平均値に揖いて両者の差違は大きくなる。GA を利用して、最適解のみならず最適解に準ずるいくつかの解を求め

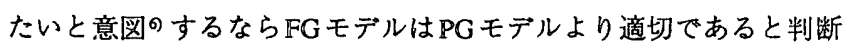
される。すなわち、上記 1. は同一計算量とした比較でも成立する。

Fモデルでは各個体は評価值に関係なく親に劣らない優秀な次世 代を残すことができる。このため、重要な遺伝子を持った個体が少 しづつ評価值を増加させる作用（進化の過程）を維持できる。一方、 Pモデルでは評価値の低い個体は $1 / 3$ の確率でビット表現の遺伝子を 次世代に引き継ぐことができるものの、次の世代も評価值が低けれ ば造伝子はその時点にお林評価值の高い個体のものに置き換わる。 そのため、重要な遗伝子を有していても、それが評価值を高める前 に消滅する確率が高くなる。この違いがモデルの効率の相違となっ ていると判断される。

\section{4-4固定荷重の大きさと桁行き方向長さ}

固定荷重の大きさが異なるふたつのモデルを設定して、桁行き方 向長さと最小重量解の関係を検討する。ひとつは固定荷重 $q_{d}=80 \mathrm{kgf} /$ $\mathrm{m}^{2}$ 、他方は $q_{d}=50 \mathrm{kgf} / \mathrm{m}^{2}$ である。後者は積雪の少ない地域の標準的な 固定荷重である。短期の積雪荷重 $q_{\text {sonow }}$ は共に $60 \mathrm{kgf} / \mathrm{m}^{2}$ とした。解法 はFG モデルを採用し、突然変異の確率を 0.09 として、世代数 1200 までの試行解析を 5 回行い、得られた最小重量解について検討する。

固定荷重 $80 \mathrm{kgf} / \mathrm{m}^{2}$ 、軒高 $600 \mathrm{~cm}$ 、スパン $2400 \mathrm{~cm}$ 、桁行き方向長さ をパラメータとし、多スパン山形フレーム構造の最小重量問題を検 討する。得られた最良解（単位平面あたりの構造体重量）と桁行き 方向のスパン数 $n_{x}$ の関係、および得られた最適解との関係をFig.5に 示す。図中 $n_{x}$ が6、8、10、12、14 の解はそれぞれ $\triangle 、 \square 、 O 、 \triangle 、$ 口印を付けて、最適解となる解には○印が併せて付されている。こ れらの解析結果からこの最小重量設計では各 $n_{x} に$ 対応する極小の重 量を与える解が存在することが分かる。これらの極小の重量と桁行 き方向長さとの関係をTable 5に数值を用いて示す。下線を付した值 は各街行き方向長さに対応して得られた最適解の值である。

固定荷重 $50 \mathrm{kgf} / \mathrm{m}^{2}$ として得られた同様な最良解（単位平面あたり の構造体重量) と行行き方向の梁間の数 $n_{x}$ の関係、および得られた 最適解との関係を Fig.6に示す。図中の印はFig.5 と同一である。
Table 5 Min. Wu corresponding to $n_{x}\left(q_{d}=80 \mathrm{kgf} / \mathrm{m}^{2}\right)$

\begin{tabular}{|l|lllll|}
\hline$L \mathrm{~cm}$ & $n_{x}=6$ & $n_{x}=8$ & $n_{x}=10$ & $n_{x}=12$ & $n_{x}=14$ \\
\hline 2400 & $\underline{16.23}$ & & & & \\
3000 & 17.80 & $\underline{17.09}$ & & & \\
3600 & $\underline{18.06}$ & 18.40 & 18.41 & & \\
3900 & 19.30 & 18.91 & $\underline{18.26}$ & & \\
4200 & 19.85 & $\underline{18.85}$ & 19.96 & 19.14 & \\
4800 & & $\underline{20.84}$ & 21.64 & 22.33 & \\
5400 & & $\underline{24.30}$ & 25.89 & 25.80 & \\
6000 & & 26.53 & 26.16 & $\underline{25.58}$ & \\
6600 & & 27.69 & $\underline{25.50}$ & 25.77 & 26.81 \\
7200 & & 25.89 & 26.65 & 26.09 & $\underline{25.09}$ \\
\hline
\end{tabular}

Table 6 The Best Solution of A Gable Frame Structure $\left(q_{d}=80 \mathrm{kgf} / \mathrm{m}^{2}\right)$

\begin{tabular}{|l|lcccccl|}
\hline $\begin{array}{l}L \\
\mathrm{~cm}\end{array}$ & $\begin{array}{l}W u \\
\mathrm{kgf} / \mathrm{m}^{2}\end{array}$ & $\tan \phi$ & $n_{y}$ & $n_{x}$ & $\begin{array}{l}\text { No. } \mathrm{H} \\
\mathrm{GBL}\end{array}$ & $\begin{array}{l}\text { No.H } \\
\text { beam }\end{array}$ & $\begin{array}{l}\text { brace installation } \\
\text { for each roof plate }\end{array}$ \\
\hline 2400 & 16.23 & 0.3 & 3 & 6 & 5 & 1 & 211112 \\
3000 & 17.09 & 0.3 & 3 & 8 & 5 & 1 & 32111123 \\
3600 & 18.06 & 0.4 & 2 & 6 & 7 & 6 & 331133 \\
3900 & 18.26 & 0.4 & 2 & 10 & 5 & 3 & 3622222263 \\
4200 & 18.85 & 0.4 & 2 & 8 & 7 & 5 & 44311344 \\
4800 & 20.84 & 0.4 & 2 & 8 & 7 & 7 & 76633667 \\
5400 & 24.30 & 0.4 & 2 & 8 & 10 & 7 & 76633667 \\
6000 & 25.58 & 0.1 & 2 & 12 & 13 & 3 & 111111111111 \\
6600 & 25.50 & 0.05 & 2 & 10 & 15 & 5 & 1111111111 \\
7200 & 25.09 & 0.1 & 2 & 14 & 13 & 3 & 11111111111111 \\
7800 & 24.93 & 0.15 & 3 & 14 & 13 & 2 & 21111111111112 \\
\hline
\end{tabular}

Table 7 The Best Solution of A Gable Frame Structure $\left(q_{d}=50 \mathrm{kgf} / \mathrm{m}^{2}\right)$

\begin{tabular}{|c|c|c|c|c|c|c|c|}
\hline $\begin{array}{l}L \\
\mathrm{~cm}\end{array}$ & $\begin{array}{l}\mathrm{Wu} \\
\mathrm{kgf} / \mathrm{m}^{2}\end{array}$ & $\tan \phi$ & $n_{y}$ & $n_{x}$ & $\begin{array}{l}\text { No. } \mathrm{H} \\
\text { GBL }\end{array}$ & $\begin{array}{l}\text { No.H } \\
\text { Beam }\end{array}$ & $\begin{array}{l}\text { brace installation } \\
\text { for each roof plate }\end{array}$ \\
\hline 2400 & 13.71 & 0.2 & 2 & 4 & 5 & 4 & 2112 \\
\hline 3000 & 14.06 & 0.25 & 2 & 6 & 5 & 2 & 211112 \\
\hline 3600 & 14.08 & 0.25 & 2 & 6 & 5 & 4 & 232232 \\
\hline 3900 & 14.40 & 0.3 & 2 & 6 & 5 & 5 & 321123 \\
\hline 4200 & 14.72 & 0.3 & 2 & 8 & 5 & 3 & 32222223 \\
\hline 4800 & 15.93 & 0.3 & 2 & 8 & 5 & 5 & 44422444 \\
\hline 5400 & 17.49 & 0.3 & 2 & 8 & 7 & 5 & 68333386 \\
\hline 6000 & 19.66 & 0.3 & 2 & 8 & 9 & 6 & 68333386 \\
\hline 6600 & 19.44 & 0.05 & 2 & 8 & 13 & 5 & 11111111 \\
\hline 7200 & 19.93 & 0.15 & 2 & 12 & 11 & 3 & 211111111112 \\
\hline 7800 & 20.10 & 0.05 & 2 & 10 & 13 & 5 & 1111111111 \\
\hline
\end{tabular}

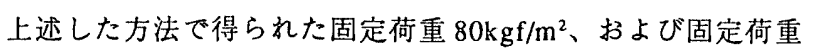
$50 \mathrm{kgf} / \mathrm{m}^{2}$ とした析行き方向長さ $2400 \mathrm{~cm}$ から $7800 \mathrm{~cm}$ モデルの最適解 の単位面積当りの重量、屋根勾配、 $n_{y} 、 n_{x}$ 山形フレームとはりの $\mathrm{H}$ 型鋼の規格に対応するTable 3の番号、および一枚の屋根の各山形フ レーム間に取り付けられるべきブレースの数をそれぞれTable 6およ び Table 7に示す。これらから次のことが分かる。

1. 桁行き方向長さ $L$ が $6000 \mathrm{~cm}$ を越えると（形状比 $2.5\left(=L / L_{y}\right)$ 以 上、、必要な屋根ブレースが少なく、屋根勾配も小さい、三次元の折 板効果を期待しないフレームが最適解となる。各山形フレームは二 次元的な挙動をすることが予測される。

2. 桁行き方向長さ $L か ゙ 6000 \mathrm{~cm}$ (形状比 2.5 ) より小さい領域で三次 元の折板効果に起因する構造体重量の軽減化が可能である。この領 
域では屋根勾配は 0.3 から 0.4 の值をとる。形状比が 1 の多スパン山 形フレーム構造の単位面積当りの重量は二次元的な挙動をするフ レームの $65 \%$ 程度の値となる。

3. 長さ $L$ と単位面積当りの構造体重量の図から判断すると、この 長さ $3600 \mathrm{~cm}$ (形状比 1.5) 以下の領域では屋根の剪断剛性の効果が大 きく桁行き方向長さ $L$ の増加に対する重量の増分は小さい。一方、 長さ $L>4200 \mathrm{~cm}$ の領域では、屋根の剪断剛性と曲げ剛性の両方の剛 性を高めた最適解が出現する。はり材の断面が大きくなり、桁行き 方向長さLの増加に対する単位面積当りの重量の増分は大きくなる。

\section{5. まとめ}

構造解析法としてこの構造をTimoshenko梁に置換して解析する力 法、および最適解析法としてGA 適用して解析し、多スパン山形 フレーム構造の平面形状、および軒高を与え、屋根の勾配、山形フ レームのピッチ、および断面性能、はりのピッチ、および断面性能、 屋根板のブレースの配置数等を制御する最小重量設計を行い、次の ような知見を得た。

1：GAにおける親の選択淘汰を行う上でふたつのモデル(Fモデル、 およびPモデル）を検討し、親子において適応度が高い個体を残す Fモデルの方が全人口のなかで適応度の高い個体を残すPモデル(世 代ギャップ $=0.5$ とした）より高い性能を発揮した。

2. 数字をビット表現する方法として、グレイコードの方がバイナ リコードより能率を向上させる効果を示した。

3. スパン $2400 \mathrm{~cm}$ 、軒高 $600 \mathrm{~cm}$ の多スパン山形フレーム構造をモデ ルとして、2 種類の固定荷重を設定し、桁行き方向長さに依存する 最小重量設計の解析を行った。

4. 多スパン山形フレームの最小重量設計の解は三次元効果をも反 映する最適解を導き出し、立体フレームの三次元的な応力伝達機能 を有効に評価するひとつの方法にもなり得る。

5. 多スパン山形フレームの平面形状の比が 2.5 以上になると三次元 効果は期待できない。この比が 2.5 以下の領域において、屋根板の三 次元効果に起因して多スパン山形フレーム構造の面積当りの主要構 造体重量を小さくする効果が観測される。ここで用いた形状比 1 の モデルの単位面積当りの重量は、二次元的な挙動をするフレームの $65 \%$ 程度となる。

\section{参考文献}

1) D.E.Goldberg : Genetic Algorithms in Search,Optimization, and Machine Learning, ADDISON-WESLEY,1989

2) R.Le Riche and R.T.Haftka : Optimization of Laminate Stacking Sequence for Buckling Load Maximization by Genetic Algorithm, AIAA J., vol.31, No.5, pp.951. 956, 1993

3）北野宏明編：遗伝的アルゴリズム、産業図書,1993

4) L. アービス編 : 遺伝的アルゴリズムハンドブック、森北出版,1994

5）大崎純: 遺伝的アルゴリズムに基づく不連続コスト関数を有する構造物 の最適設計法、日本建築学会構造系論文集、第464 号、pp.119-127、1994年 6) 林康裕、護雅史:GA と樹形モアルを用いた制振構造物の創生的基本計画、 日本建築学会構造系論文集、第 480 号、pp.47-56、1996 年 7) 三井和男、登坂宣好: 遺伝的アルゴリズムの空間構造形態解析への応用、 日本建築学会構造系論文集、第 484 号、pp.75-83、1996年

8) Y.Minakawa : Timoshenko Beam Theories for Folded Plate Effect of Multispan
Gable Frame Structures, Part I A case of asymmetric deformations, Journal of Structural And Construction Engineering、No.483, pp.99-109,1996

9) Y.Minakawa : Timoshenko Beam Theories for.Folded Plate Effect of Multispan Gable Frame Structures, Part II A case of symmetric deformations, Journal of Structural And Construction Engineering、No.489, pp.47-58,1996

10) Caruana,R.A. and J.D.Schaffer : Representation and hidden bias : Gray vs. Binary Coding for Genetic Algorithms Proceedings of the Fifth International Conference on Machine Learning,pp.153-161. Ann Arbor, Mich.,1988

\section{付録 多スパン山形フレーム構造のはり置換理論の概要}

この構造（Fig.1）は棟に関して対称な構造であると仮定する。こ の構造の変形を棟に関する対称変形と逆対称変形に分けて考える。 これに伴い荷重もこれら2つの成分（Fig.2）に分解して扱う。これ らふたつの変形は、後述する仮定を導入して算定すると、煎断変形 を考慮したはりに置換される。このとき、屋根板の三次元的なつり あいは満足される。このはり置換理論の覜要を示す。

\section{A1. 対称変形の汎関数 9}

屋根板を直交䀧方性、捻れ剛性を持たない平板とモデル化する。デ

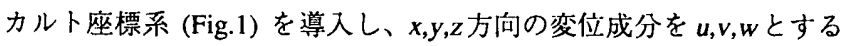
と、この変形の沉関数は次式のように表される。

$$
\begin{aligned}
& \Pi_{1}^{s}\left(u, v, w, N_{y} H, R\right)=2\left[\int _ { 0 } ^ { L / 2 } \left[\int _ { - a / 2 } ^ { a / 2 } \left\{\frac { 1 } { 2 } \left\{C_{1} u_{, x}^{2}+2 N_{y} v_{y}-N_{y}^{2} / C_{2}\right.\right.\right.\right. \\
& \left.+C_{12}\left(u_{y}+v_{x}\right)^{2}+D_{1} w_{, x x}^{2}+D_{2} w_{y y}^{2}\right\}+q_{s g}(w \cos \phi+v \sin \phi) \cos \phi \\
& \left.+q_{s n} w\right\} d y+\left.H(w \sin \phi-v \cos \phi)\right|_{y=-a / 2}+\left.R(w \cos \phi+v \sin \phi)\right|_{y=-a / 2} \\
& \left.\left.+\left.M_{s c} w_{y}\right|_{y=-a / 2}-\left.H_{s c}(v \cos \phi-w \sin \phi)\right|_{y=-a / 2}\right] d x\right]
\end{aligned}
$$

ここに、屋根板が $y$ 方向に伸縮しない条件を導入するため、この方 向のひずみエネルギはHellinger-Reissner型のそ礼を用い、棟の水平変 位がゼロ、および柱の伸縮がゼロの条件に対応する Lagrange 乗数を

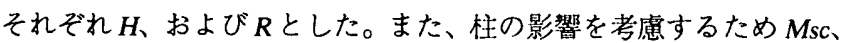
およびHscの未定係数を導入した。Msc、および Hscは柱の曲げ岡性、 柱脚の境界条件を考虑すれば、直交異方性の屋根板の軒位置の境界 条件に変換される。

\section{A2. 逆対称変形の沉関数 8}

対称変形と同様に屋根板を直交異方性、捻れ剛性を持たない平板 とモデル化すると、この変形の汎関数は次式のように表される。

$$
\begin{aligned}
& \Pi_{1}^{a}\left(u, v, w, N_{y}, R_{1}, R_{2}\right)=2\left[\int _ { 0 } ^ { L / 2 } \left[\int _ { a / 2 } ^ { a / 2 } \left\{\frac { 1 } { 2 } \left\{C_{1} u_{x}^{2}+2 N_{y}{ }_{, y}-N_{y}^{2} / C_{2}\right.\right.\right.\right. \\
& \left.\quad+C_{12}\left(u_{y}+v_{, x}\right)^{2}+D_{1} w_{, x x}^{2}+D_{2} w_{y y}^{2}\right\}+q_{a g}(w \cos \phi+v \sin \phi) \cos \phi \\
& \left.+q_{a n} w\right\} d y+\left.R_{1}(w \cos \phi+v \sin \phi)\right|_{y=a / 2}+\left.R_{2}(w \cos \phi+v \sin \phi)\right|_{y=-a / 2} \\
& \left.\left.+\left.M_{a c} w_{y}\right|_{y=-a / 2}-\left.H_{a c}(v \cos \phi-w \sin \phi)\right|_{y=-a / 2}\right] d x\right]
\end{aligned}
$$

ここに、y方向のひずみエネルギは Hellinger-Reissner 型のそれを用 い、棟の鉛直変位がゼロ、および柱の伸縮がゼ口の条件に対応する Lagrange 乗数をそれぞれR1、およびR2とした。また、柱の影響を考 慮するため Mac、および Hacの未定係数を導入した。Mac、および $\mathrm{Hac}$ は柱の曲げ剈性、柱脚の境界条件を考慮すれば、直交異方性の屋根 板の軒位置の境界条件に変換される。 


\section{A3. はり理論置換上の仮定}

はり理論に置換するために次の仮定を導入する。

1) 屋根板を桁行き方向曲げ剛性、および捻れ剛性を持たない直交

異方性平板とモデル化する。すなわち、次式を仮定する。

$D 1=0, D 12=0$

(A.4) 式の禿件は既に (A.1)、(A.2) 式に導入されている。

2) 山形フレームの柱は伸縮しない。

3) 山形フレームのはりは伸縮しない。

4) 屋根板の桁行き方向のひずみは直線的に分布する。

\section{A4. 変形の表現}

\section{A4-1 対称变形}

山形フレームのはりの部材角をRsとし、仮定3)、および仮定4)を 考應して、対称変形時の変位 $v$ は次式のように表される。 $v(x, y)=R_{s}(x) a \sin \phi \cos \phi$

$x$ 方向の軸変位を us、屋根板の法線周りの回転を $\theta s$ とし、仮定 4)

を考慮して、この変形時の変位 $\mathrm{u}$ は次式のように表される。

$$
u(x, y)=u_{s}(x)-y \theta_{s}(x)
$$

\section{A4-2 逆対称変形}

棈の水平変位を $d H$ とし、仮定3）を考慮すると、逆対称変形時の変 位 vは次式のように表される。

$$
v(x, y)=d_{H}(x) \cos \phi
$$

槙位置での鉛直軸周りの回転を $\theta z$ とすると、この変形時の変位 $u$ は次式のように表される。

$$
u(x, y)=-\theta_{z}(x)(y-a / 2) \cos \phi
$$

\section{A5. はり置換理論}

\section{A5-1 封称変形のはり置換理論}

(A.1) 式から得られる屋根板の $y$ 、および $z$ 方向のつりあい式を対 称変形時の境界条件の下で解析し、(A.5)、および (A.6) 式を代入し て変分式の境界項を評価すると、対称変形時のはり置換理論のつり あい式を得る。このつりあい式に対応するはり置換理論の沉関数は (1)式のように表される。この汎関数の表現に利用したはりとしての 断面性能は次式のように表される。

$(E A)_{n}^{s}=\left(a / s_{y}+1\right) C_{1}=\left(a / s_{y}+1\right) E A_{x}\left(1+c^{3} A_{b r} / A_{x}\right)$

$(E I)_{n}^{s}=\left\{E A_{x}\left(1+c^{3} A_{b J} / A_{x}\right) / s_{y}\right\} a^{3}\left(1+s_{y} / a\right)\left(1+2 s_{y} / a\right) / 12$

$(G A)_{n}^{s}=E A_{b r i} s_{x} s_{y}^{2} /\left(s_{x}^{2}+s_{y}^{2}\right)^{3 / 2}$

一故の屋根板のはりとしての軸力、曲げモーメント、および剪断 力は次式のように表される。

$N_{n}^{s}=(E A)_{n}^{s} u_{s, x} \quad, M_{n}^{s}=(E I)_{n}^{s} \theta_{s, x}$

$Q_{n}^{s}=(G A)_{n}^{s}\left(a R_{s, x} \sin \phi \cos \phi-\theta_{s}\right)$

屋根板の変位成分 $w$ 、面内力 $N y$ 、曲げモーメント $M y$ 、換算剪断力 Vyはそれぞれ次式のように表される。

$w(y)=\left[a R_{s}\{(3+2(4+3 \gamma) \cos 2 \phi) / 4+(y / a)(9(1+\gamma)-6 y / a\right.$

$\left.\left.-4(1+3 \gamma)(y / a)^{2}\right) / 2-3 \gamma\left(a / h_{c}\right) f_{4} \sin \phi\right\}+a^{3} f_{4}\left\{q_{s c} h_{c}^{2} / a\right.$

$\left.\left.-\left(q_{s n}+q_{s_{8}} \cos ^{2} \phi\right)(a(8+3 \gamma)+2 y(4+3 \gamma)) / 6\right\} /\left(8 D_{2}\right)\right] /(4+3 \gamma)$

where $f_{4}(y)=(y / a-1 / 2)^{2}(y / a+1 / 2)$

$N_{\mathrm{y}}(y)=\left[12 D_{2} R_{s}\left\{3 \gamma(3-\cos 2 \phi)+4\left((1+3 \gamma)\left(h_{c} / a\right)+\gamma\left(a / h_{c}\right)\right) \sin \phi\right\} /\left(a h_{c}\right)\right.$

$-4(4+3 \gamma) H_{s}-q_{s c} h_{c}\left\{2(5+3 \gamma)+3\left(h_{d} a\right) \sin \phi\right\}-q_{s n} a\left\{6(1+\gamma) \sin \phi+\gamma\left(a / h_{c}\right)\right\}$

$\left.+q_{s g} a\left[-\gamma\left(a / h_{c}\right)+2(1+2(4+3 \gamma) y / a) \sin \phi\right\} \cos ^{2} \phi\right] /\{4(4+3 \gamma) \cos \phi\}$ (A.12)
$M_{y}=\left[-3\left(D_{2} / a\right) R_{s}\left\{2+4(1+3 \gamma) y / a+\gamma(6 y / a-1)\left(a / h_{c}\right) \sin \phi\right\}\right.$

$+q_{s c} h_{c}^{2}(6 y / a-1) / 8$

$\left.+\left(q_{s n}+q_{s g} \cos ^{2} \phi\right) a^{2}\left\{2+\gamma-4 y / a-4(4+3 \gamma)(y / a)^{2}\right\} / 8\right] /(4+3 \gamma)$

$V_{y}(y)=\left[-12 D_{2} R_{s}\left(2(1+3 \gamma)+3 \gamma\left(a / h_{c}\right) \sin \phi\right\} / a^{2}+q_{s c}\left(3 h_{c}^{2}\right) /(2 a)\right.$

$\left.-\left(q_{s n}+q_{s g} \cos ^{2} \phi\right)\{a+2 y(4+3 \gamma)\}\right] /\{2(4+3 \gamma)\}$

$N y$ 、および Vyを用いて、柱頭部の桁行き方向単位長さ当たり剪断 応力 Hsc、および軸力 $R$ は次式のように表される。

$H_{s c}=-N_{y} \cos \phi-V_{y} \sin \phi$

$R=N_{y} \sin \phi-V_{y} \cos \phi$

\section{A5-2 逆対称変形のはり置換理論}

(A.2) 式から得られる屋根板の $y$ 、および $z$ 方向のつりあい式を逆 対称変形時の境界条件の下で解析し、(A.7)、および (A.8) 式を代 入して変分式の境界貢を評価すると、逆対称変形封のはり置換理論 のつりあい式を得る。このつりあい式に対忍するはり置換理論の汎 関数は (2) 式のように表される。この沉関数の表現に利用したはり としての断面性能は次式のように表される。

$(E I)_{z}^{a}=(2 / 3)\left\{E A_{x}\left(1+c^{3} A_{b} / A_{x}\right) / s_{y}\right\} a^{3}\left(1+s_{y} / a\right)\left(1+s_{y} /(2 a)\right) \cos ^{2} \phi(\mathrm{A} .17-1)$ $(G A)_{z}^{a}=2\left\{E A_{b r} s_{x} s_{y}^{2} /\left(s_{x}^{2}+s_{y}^{2}\right)^{3 / 2}\right\} \cos ^{2} \phi$

二枚の屋根板全体のはりとしての曲げモーメント、および剪断力 は次式のように表される。

$M_{2}^{a}=(E I)_{z}^{a} \theta_{2, x} \cos ^{2} \phi$

(A.18-1)

$Q_{z}^{a}=(G A)_{z}^{a}\left(d_{H, x}-\theta_{z}\right) \cos ^{2} \phi$

(A.18-2)

山形フレームの合応力を定めるのに必要な屋根板の变位成分W、面 内力 $N y$ 、曲げモーメント $M y$ 、換算剪断力 $V y$ はそれぞれ次式のよう に表される。

$w(y)=-d_{H}\left[\sin \phi+\not\left(y^{2} / a^{2}-1 / 4\right)(y / a-3 / 2) a /\left\{2 h_{c}(1+\gamma)\right\}\right]$

$+a\left(y^{2} / a^{2}-1 / 4\right)\left[q_{a c} h_{c}^{2}(2 y-3 a)+\left(q_{a n}+q_{a g} \cos ^{2} \phi\right) a\left\{(5+2 \gamma) a^{2}\right.\right.$

$\left.\left.+2 a y y-4(1+\gamma) y^{2}\right\}\right] /\left\{96(1+\gamma) D_{2}\right\}$

(A.19)

$N_{y}=\tan \phi\left[3 \gamma D_{2} d_{H} /\left(a^{2} h_{c}\right)-q_{a c} h_{c}^{2} /(8 a)\right.$

$\left.+q_{a n} a(4+3 \gamma) / 8+q_{a g}(y(1+\gamma)-a \gamma / 8) \cos ^{2} \phi\right] /(1+\gamma)$

(A.20)

$M_{y}=(1-2 y / a)\left[-q_{a c} h_{c}^{2}+\left(q_{a n}+q_{a g} \cos ^{2} \phi\right) a^{2}\{2+\gamma\right.$

$\left.+4(1+\gamma) y / a\}+24 \gamma D_{2} d_{H} /\left(a h_{c}\right)\right] /\{16(1+\gamma)\}$

$V_{y}=-\left[3 \gamma D_{2} d_{H} /\left(a^{2} h_{c}\right)-q_{a c} h_{c}^{2} /(8 a)\right.$

$\left.+\left(q_{a n}+q_{a g} \cos ^{2} \phi\right)(y(1+\gamma)-a \gamma / 8)\right] /(1+\gamma)$

$N y$ 、および $V y$ を用いて、柱頭部の桁行き方和単位長さ当たり剪断 応力 Hac、および軸力 $R 2$ は次式のように表される。

$H_{a c}=-N_{y} \cos \phi-V_{y} \sin \phi$

$R_{2}=N_{y} \sin \phi-V_{y} \cos \phi$

P.S. 文献 8、および文献 9 の変数 ny の表示に誤記が有った。下記の ように訂正する。 $n y=2 \mathrm{a} / \mathrm{sy} \rightarrow n y=\mathrm{a} / \mathrm{sy}$

この說記は解析結果に影響を与えていない。

（1997年3月10日原稿受理，1997年6月24日採用決定） 